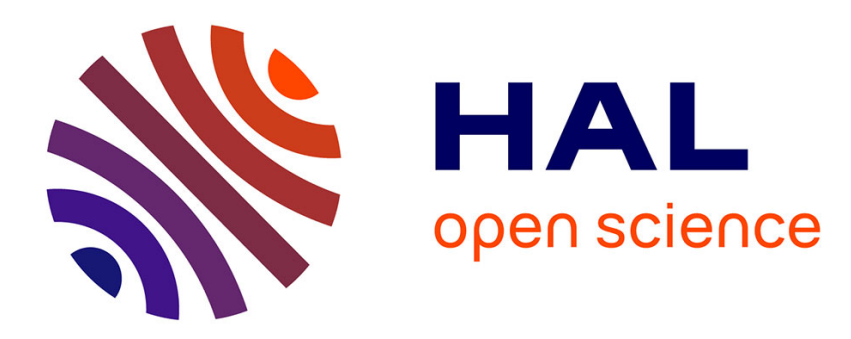

\title{
Romance Monosyllabic Imperatives and Markedness
}

Franck Floricic, Lucia Molinu

\section{To cite this version:}

Franck Floricic, Lucia Molinu. Romance Monosyllabic Imperatives and Markedness. Thomas Stolz, Nicole Nau, Cornelia Stroh. Monosyllables: from phonology to typology, Akademie Verlag, pp.149172, 2012, STUF Studia Typologica. halshs-00756954

\section{HAL Id: halshs-00756954 https://shs.hal.science/halshs-00756954}

Submitted on 26 Nov 2012

HAL is a multi-disciplinary open access archive for the deposit and dissemination of scientific research documents, whether they are published or not. The documents may come from teaching and research institutions in France or abroad, or from public or private research centers.
L'archive ouverte pluridisciplinaire HAL, est destinée au dépôt et à la diffusion de documents scientifiques de niveau recherche, publiés ou non, émanant des établissements d'enseignement et de recherche français ou étrangers, des laboratoires publics ou privés. 


\title{
FranCK Floricic (PARIS/FranCE) \& LuCIA MOLINU (TOULOUSE/ FRANCE)
}

\section{Romance monosyllabic imperatives and markedness}

\begin{abstract}
The aim of this paper is to account for the particular shape of some Romance imperatives. It has long been recognized that imperatives often equal the bare stem and their morphological make-up reflects their primitive status in language acquisition. It will be shown that in Romance some imperatives can even go farther in phonetic reduction: the verb stem can be radically amputated and the possible reasons for such a drastic reduction will be discussed. It will be argued that phonological subminimality arises even in those languages in which minimal size restrictions have been taken to be at work. The question of frequency will be addressed, and the view will be held that subminimality produces phonologically marked structures which cannot be accounted for by resorting to frequency effects: though frequency appears to be relevant, it will be argued that monosyllabic imperatives are structurally marked and that markedness stems from the speech-rooted nature of imperatives.
\end{abstract}

Nam tres istae voces intra, citra, ultra, quibus certi locorum fines demonstrantur, singularibus apud veteres syllabis appellabantur in, cis, uls. VIII. Haec deinde particulae quoniam parvo exiguoque sonitu obscurius promebantur, addita est tribus omnibus eadem syllaba, et quod dicebatur cis Tiberim et uls Tiberim, dici coeptum est citra Tiberim et ultra Tiberim; item quod erat in, accedente eadem syllaba intra factum est.[For those three words intra, citra, ultra (within, this side, beyond), by which definite boundaries of places are indicated, among the early writers were expressed by monosyllables, in, cis, uls. Then, since these particles had a somewhat obscure utterance because of their brief and slight sound, the same syllable was added to all three words, and what was formerly cis Tiberim (on this side of the Tiber) and uls Tiberim (beyond the Tiber) began to be called citra Tiberim and ultra Tiberim; and in also became intra by the addition of the same syllable (Gellius, A. Cornelius, Noctes Atticae [Attic Nights]. Loeb Classical Library (Vol. II), 1927)] 


\section{Introduction}

The aim of this work is to account for a small class of Romance verb forms, monosyllabic imperatives. Imperatives have long been neglected in the linguistic literature, where they were only dealt with as a peripheral topic in Pragmatics. In fact, imperatives are a fascinating topic, their interest lying precisely in the fact that they concern all aspects of linguistic analysis: syntax, morphology, pragmatics, and of course phonology. Given the multiplicity of the perspectives from which the analysis could be proposed, we shall concentrate on the morpho-phonological side of the question; in particular, we shall raise the question as to whether our imperatives can be said to obey some Minimality Constraints, and we shall argue that such Minimality Constraints are clearly violated by monosyllabic imperatives. And this in turn will raise the question as to whether such Minimality Constraints are active in the languages under review. The question of markedness will be discussed and it will be asked in which sense our imperatives are "marked". We shall argue that the markedness of some of our monosyllabic imperatives does not reduce to frequency effects.

\section{The imperatives}

One of the most important properties which imperatives share with, say, vocatives, is their speech-rooted character. As a matter of fact, both are directed towards the addressee, whether for naming purposes, or for a command. As such, imperatives are distinguished by their prosodic properties, as is clearly seen in cases where imperatives and indicatives are morphologically syncretic. In standard Italian, a sentence like mangia la pasta 'he is eating the pasta' is a mere statement with a constative value in the prosodically neutral variant mangia la pasta, ('(s)he is eating the pasta') but it clearly fulfils a directive function when uttered with the appropriate intonational contour: mangia la pasta! ('eat the pasta!')

A property which has long been pointed out is the importance of the beginning of the word. It is a well-known fact, identified by Kruszewski and Schuchardt among others, that the beginning of the word plays a crucial role in word recognition. As Kruszewski (1883/1995: 85) puts it,

Perhaps both the accelerated metamorphosis of the medial sounds of a word and the instability of the final sounds can be explained primarily by the fact that the main carriers of meaning are the initial sounds; we, so to speak, resort to abbreviations in pronunciation, holding to the same principle that we do in writing: we show special care for the beginning and less for the end of a word. 
In imperatives and vocatives, the beginning of the word is even more important, given that their intonational contour marks the very nature of the speech act at stake. And this is also the reason why the endings of these categories are so often truncated.

Last, it must be pointed out that the intonational contour of imperatives is correlated with their on-focus value. In languages endowed with a complex focus system, it is not unusual to find that focus marking is suspended in the imperative, the reason being that the imperative carries by itself a focus value, thus pre-empting any focus marking in the other elements of the sentence (cf. Floricic 2009 and the literature cited therein). From the morpho-phonological point of view, one of the most striking features of imperatives is their bareness and their shortness (cf. Lombard 1953: 21), and these properties iconically reflect the immediate - we should say non-mediated - relationship carried out by the 2 nd person singular imperative. The relationship implied by imperatives can be defined as asymmetrical in so far as the terminus a quo of the relationship is backgrounded, while putting in the forth its terminus ad quem. In other words, imperatives like vocatives are polarized around the addressee, and the verb or the nominal stem is deprived of any inflexional information, thus offering the bare expression of the state of affairs to be conformed with, or of the individual to be identified.

\subsection{Minimality effects}

It has long been recognized that the size of independent words should not be inferior to a given prosodic scheme. This was for example the view of Antoine Meillet in his analysis of Old Armenian aorists. When asking why Old Armenian has kept the augment in the third person singular, Meillet (1900: 16) rightly points out that:

Les formes grammaticales très brèves sont souvent éliminées au profit de formations plus longues et ayant plus de corps phonétique. C'est à cette tendance qu'est due, on le sait, la conservation de l'augment en arménien ancien. La 3ème personne du singulier de l'aoriste a l'augment dans tous les cas où, sans augment, elle serait monosyllabique : beri, eber; baçi, ebaç; l'augment arménien étant toujours syllabique, les verbes qui commencent par une voyelle en sont dépourvus dans les textes les plus anciens : arbi, arb; par la suite, les verbes à initiale vocalique ont reçu aussi l'augment syllabique, d'où earb. Les aoristes edi 'je posai' et $e k i$ 'je vins' ont l'augment à toutes les personnes parce que, sans cela, ils seraient monosyllabiques dans toute leur flexion; etu 'je donnai' a de même l'augment à toutes les personnes, sauf la lère plur. tuakh. [Very short grammatical forms often are eliminated in favour of longer formations with major phonetic substance. It is a well known fact that conservation of the augment in Old Armenian is due to this very tendency. The third person singular in the aorist takes the augment in those cases where otherwise it would be monosyllabic: beri, eber; 
baçi, ebaç; given that the Armenian augment always is syllabic, verbs with an initial vowel are augmentless in the oldest texts: $a r b i, a r b$; subsequently, verbs with an initial vowel have received the syllabic augment, hence éarb. Aorists $e d i$ 'I put, placed' and $e k i$ 'I came' take the augment in all the persons because otherwise they would be monosyllabic in the whole paradigm; etu 'I gave' takes as well the augment in all the persons, except the first plural tuakh].

We shall not discuss in this paper the views of Robert Gauthiot ${ }^{1}$, who devoted a whole chapter of his dissertation to the properties of monosyllables, nor shall we discuss the views of Jacob Wackernagel, who devoted his pioneering work Wortumfang und Wortform to the crosslinguistic tendency to avoid "Einsilbigkeit".

The point to be stressed is that the shape of the minimal prosodic unit can vary from language to language, but everywhere in the world one finds examples of languages in which such a prosodic constraint is at work. Minimal word restrictions have been reported in various phonological processes, among which we can mention the formation of hypocoristics, morphological truncation, clippings, etc. Much less attention has been devoted to vocatives and imperatives, and when they have been called into question, they have usually been claimed to obey Minimality Constraints. In many African languages, the imperative is one of the most naked forms. The data in (1a) are from Ndebele, a Bantu language spoken in Zimbabwe, and they show that the second person imperative equals the infinitive, minus the infinitive marker úkú (cf. Downing 2000: 25). With monosyllabic roots, however, Hyman et al. (2008) points out that the "stem cannot occur in its bare form in the imperative, but rather acquires an augmentative syllable yi-" (cf. (1b)):

The same pattern can be observed in Siswati, another Bantu language mainly spoken in Swaziland. Herman (1996: 39) holds that "There is no word in Siswati that is shorter than two syllables long (with a word in the phonological sense being something which can stand by itself)". And imperatives show that such a constraint is at work: with polysyllabic roots, the imperative is the bare stem, just like in Ndebele:

(1) The minimal word in Ndebele (Downing 2000: 25; Hyman 2008)

(1a) Multisyllabic Infinitive Imperative Gloss

\begin{tabular}{|c|c|c|}
\hline nitial & $\begin{array}{l}u^{u} \dot{u}^{\prime}=d o: n s a \\
u^{\prime} k \dot{u}=b h u k \dot{u}: t s h a\end{array}$ & $\begin{array}{l}\text { do:nsa } \\
\text { bhukú:tsha }\end{array}$ \\
\hline
\end{tabular}

1 "L'intérêt particulier des monosyllabes se manifeste encore par ailleurs. Leur brièveté les a entraînés à d'autres modifications variées dans la forme mais qui toutes relèvent de la même tendance générale en vertu de laquelle les langues évitent d'employer comme mots normaux, autonomes, à valeur pleine, des éléments trop courts" (Gauthiot 1913: 66). [The particular interest of monosyllables offers other manifestations. Their shortness has led them to other various modifications whose justification lies in the general tendency according to which languages tend to avoid too short elements as independent and semantically full words].

2 Data and glosses are taken from the authors. 
(1b) Monosyllabic

$\begin{array}{lll}\text { úkú }=k h i: p h a & \text { khi:pha } & \text { 'to put out' } \\ \text { úkú=búthéle:la } & \text { buthelé:la } & \text { 'to heap up' } \\ \text { úkú:=lwa } & y i \text { :-lwa } & \text { 'to fight' } \\ \text { úku: }=\text { phá } & y i:-p h a ́ & \text { 'to give' } \\ \text { úkú:=fa } & y i:-f a & \text { 'to die' } \\ \text { uku-dl-a } a & y i-d l-a & \text { 'to eat' } \\ u k u-z-a & y i-z-a & \text { 'to come' } \\ \text { uku-m-a } & y i-m-a & \text { 'to stand' }\end{array}$

(2) The minimal word in Siswati (Herman 1996: 39)

$\begin{array}{llll} & \text { Infinitive } & \text { Imperative } & \text { Gloss } \\ \text { (2a) Multisyllabic } & k u-b o n-a & \text { bon- } a & \text { 'to see' } \\ & k u-b a l-a & b a l-a & \text { 'to write' } \\ & k u-l i m-a & \text { lim- } a & \text { 'to plow' } \\ & k u-b a l-a & b a l-a & \text { 'to count' } \\ & & y-a-n i & \text { 'to go' } \\ \text { (2b) Monosyllabic } a-a & k^{h}-a-n i & \text { 'to pick' } \\ & k u-k^{h}-a & t s^{h}-a-n i & \text { 'to say' } \\ & k u-t s^{h}-a & l 3-a-n i & \text { 'to eat' } \\ & k u-l y-a & \end{array}$

The examples in (2a) show that here too the imperative equals the infinitive, minus the infinitive marker $k u$ - (cf. bon- $a$ 'see!'; bal-a 'write!', etc.). With monosyllabic roots, a minimality violation follows, which is repaired by inserting an enclitic syllable $-n i-$, hence $y-a-n i$ 'go!'; $k^{h}-a-n i$ 'pick!'; $t s^{h}-a-n i$ 'say!', etc.

We shall not discuss in detail the data from Swahili reported in (3), because they show the same restrictions as those mentioned in Ndebele and Siswati. The common point between Swahili and Ndebele is that the imperative is formed deleting the infinitive marker $-k u$, but the strategy employed in order to avoid minimality is different: in the case of Swahili, the infinitive marker is preserved in those cases where the root would result subminimal (cf. (3b) ku-l-a 'eat!'; ku-nyw-a 'drink!', etc.):

(3) The minimal word in Swahili (Park 1998)

$\begin{array}{llll}\text { (3a) Multisyllabic } & \text { Infinitive } & \text { Imperative } & \text { Gloss } \\ & k u \text {-som- } a & \text { som- } a & \text { 'to read' } \\ & k u-\text { fany- } a & \text { fany- } a & \text { 'to do' } \\ & k u-k a t-a & k a t-a & \text { 'to cut' } \\ & k u \text {-sahau } & \text { sahau } & \text { 'to forget' } \\ & & k u-l-a & \text { 'to eat' } \\ \text { (3b) Monosyllabic } a-l-a & k u-n y w-a & \text { 'to drink' } \\ & k u-n y w-a & \text { njoo } & \text { 'to come' } \\ & k u-j-a & \text { nend-a } & \text { 'to go' }\end{array}$


The crucial point, however, to which we shall come back later, is that the Minimality restrictions don't apply so blindly. As a matter of fact, if the Minimality constraint holds for most monosyllabic roots, some verb forms may well be subminimal. In the Swahili dialect of Kimakunduchi, Bertoncini (1999) points out that violations of Minimality constraints can be found, and she mentions among others monosyllabic imperative forms like lya! 'eat!' (cf. Kraska-Szlenk 2009: 281):

Some dialects do not respect the minimality constraint as rigorously as Standard Swahili, as seen in the following Kimakunduchi data: the monosyllabic adjective in nguo pya 'new clothes' for Standard Swahili nguo mpya, or the monosyllabic imperative lya 'eat-sg.' for Standard kula (Bertoncini 1999).

We came across the same kind of violations in Tswana, where Denis Creissels pointed out to us (p.c.) such forms as tlá! 'come!', which is attested along with the augmented form etlá!. (see as well Zerbian, this volume).

To close this all too brief panorama, let us mention the case of Old Armenian where, as we said, the third person singular in the aorist is endowed with an augment which prevents monosyllabicity. On the contrary, the Old Armenian imperative does not surface with the augment, but rather as a bare monosyllabic stem, thus showing a violation of the ban against monosyllabic words. As recalled by Meillet (1905-1906: 359),

Seule, la deuxième personne du singulier de l'impératif, qui est par excellence la forme brève des verbes dans la plupart des langues, est restée monosyllabique (en arménien) dans ce dernier verbe (i.e. lal 'pleurer') : laç 'pleure'. [The second person singular of the imperative, which is par excellence in most languages the shortest verb form, is the only one which remained monosyllabic (in Armenian) in this verb (i.e. lal 'to cry'): lac 'cry'].

(4) Old Armenian monosyllabic imperatives

$$
\begin{array}{ll}
\text { dir 'lay!' } & \text { lac 'cry!' } \\
\text { lic 'fill!' } & \text { bac 'open!' } \\
\text { kac 'stay!' } &
\end{array}
$$

What we shall see in the remainder of this study is that for those Romance languages where Minimality constraints have been recognized, second person singular imperatives may violate such constraints.

\subsection{The Sardinian imperatives}

Let us start with a rather clear case, that of Logudorese Sardinian. The fact that a Minimality requirement is at work in this language can be seen in the examples in (5), where an epenthetic syllable has been inserted in those cases which otherwise would be subminimal (cf. Floricic \& Molinu 2003: 351): 
(5) Sardinian Repair strategies (Molinu 1999)

$\begin{array}{lll}\text { kie ['ki: } \varepsilon] & < & k i \text { ('who') } \\ \text { tie ['ti: } \varepsilon] & < & t i \text { ('you') } \\ \text { mie ['mi: } \varepsilon] & < & m i \text { ('me') } \\ \text { dae ['da: } \varepsilon] & < & d a \text { ('give!') }\end{array}$

It is clear from the examples in (5) that the Sardinian Minimal Word is a syllabic trochee. As far as Sardinian imperatives are concerned, when they are polysyllabic, they naturally meet the minimal size requirement and thus, as shown by examples such as kanta! 'sing!'; bénde! 'sell!'; drommi! 'sleep!', and fáge! 'do!' in (6), they do not violate any Minimality restrictions.

(6) Sardinian polysyllabic imperatives (Budduso' Logudorese (Molinu 1988-1989)

$\begin{array}{lll} & \text { Imperative } & \text { Indicative present } \\ \text { cantare ('to sing') } & \text { kanta } & \text { kantas (2SG), kantat (3SG) } \\ \text { béndere ('to sell') } & \text { bénde } & \text { béndes (2SG), béndet (3SG) } \\ \text { drommire ('to sleep') } & \text { drommi } & \text { drommis (2SG), drommit (3SG) } \\ \text { fágere ('to do') } & \text { fáge } & \text { fáges (2SG), fáget (3SG) }\end{array}$

However, a number of imperative forms can be found which do violate the bisyllabic pattern. These imperative forms, which are listed in (7), are all truncated versions of an already existing bisyllabic imperative:

(7) Sardinian monosyllabic imperatives (Budduso' Logudorese, Molinu 1988-89; Floricic \& Molinu 2003)

Imperative

$\begin{array}{ll}m i^{\prime} \text { ['mi] } & (<\text { mira ['mi:ra] 'look!') } \\ \left.t e^{\prime} \text { ['t } \varepsilon\right] & (<\text { tene (['tc:ne]) 'hold!') } \\ b a^{\prime} \text { ['ba] } & (<\text { bae ['ba: } \varepsilon]) \text { 'go!') } \\ t o^{\prime} \text { ['to] } & (<\text { tocca ['tok:a]) 'take!') } \\ n a^{\prime} \text { ['na] } & (<\text { nara ['nara]) 'tell!') } \\ l e^{\prime} \text { ['le] } & (<\text { lea ['lea]) 'take!') }\end{array}$

Indicative present miras (2SG), mirat (3SG)

tenes $(2 \mathrm{SG})$, tenet $(3 \mathrm{SG})$

andas $(2 \mathrm{SG})$, andat $(3 \mathrm{SG})$

toccas $(2 \mathrm{SG})$, toccat $(3 \mathrm{SG})$

naras (2SG), narat ( $3 \mathrm{SG})$

leas $(2 \mathrm{SG})$, leat $(3 \mathrm{SG})$

The feature shared by all the forms in (7) is their subminimality: whilst the basic imperative is a syllabic trochee, the derived truncated form is monosyllabic and monomoraic, thus showing a phonologically deviant pattern. Thus, the Sardinian data crucially raise at least two questions:

a) is there anything like a "minimal word constraint" in Sardinian?

b) if such a constraint really is at work, what is the reason for the Minimality violations reported in (7)?

c) must "Minimality" apply to surface forms, or should it apply to phonological representations? 
We shall return to these questions later. Let us first present the more controversial situation of Italian and Catalan.

\subsection{Imperatives and Minimality in Catalan and Italian}

In Italian, the Minimal Word has been argued to be a syllabic trochee by Thornton (1996) and (2007), whereas in Catalan it has been taken to be a moraic trochee by Cabré i Monet (1994). And both argued for such a Minimality requirement on the basis of such phenomena as the formation of hypocoristics.

\subsubsection{The case of Catalan}

As shown by examples such as bisyllabic Fina from Josefina (cf. (8a)), Tilde from Clotilde (cf. 8e)) or Mei from Remei (cf. (8h)), Catalan hypocoristics select a trochee, be it a bisyllabic trochee, or a moraic trochee, as argued by Cabré i Monet (1994).

(8) The hypocoristics in Catalan

(8a) Josefina $>\quad$ Fina, Fineta

(8b) Enriqueta $>\quad$ Queta

(8c) Josepona $>\quad$ Pona, Poneta

(8d) $\quad$ Manolita $>\quad$ Lita

(8e) Clotilde $>\quad$ Tilde

(8f) Magdalena $>\quad$ Lena

(8g) Rossita $>$ Sita

(8h) Remei $>$ Mei

(8i) Bartomeu $>$ Tomeu [tuméw]

The process generating the kind of hypocoristics mentioned in (8) can be represented as in (9):

(9)

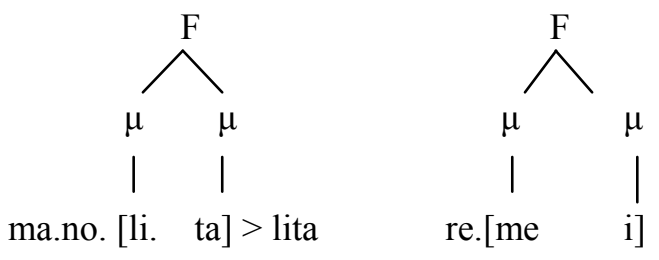

Of course it is not the aim of this paper to discuss whether or not the basic pattern of Catalan hypocoristic formation is a moraic trochee or something else. If we take into account the Catalan monosyllabic imperatives in (10), it can be argued that the moraic trochee indeed is a recurrent prosodic pattern among imperatives, as argued for by Cabré i Monet (1993): as a matter of fact, they generally show up with the scheme CVC or CVGlide. Not only is the moraic trochee the basic pattern of Catalan phonology; this 
pattern also is deemed to be responsible for the allomorphic variant of some second person singular imperatives, as argued by Cabré i Monet (1993: 81) who observes:

Cal ressaltar també que les formes imperatives de 2 ps dels verbs anar, fer, venir, no prenen les corresponents de la 3 psPI com caldria esperar, perquè questes formes no s'ajusten a les condicions del mot mínim de la llengua: va/vés, falfes, ve/vine. [It must be pointed out as well that the (2SG) Imperative forms of anar 'to go', fer 'to do', venir 'to come' don't match with the 3rd psPI as we should expect, because these forms do not obey the conditions on the Minimal Word of the language: valvés, falfes, ve/vine]

(10) Catalan monosyllabic imperatives (Moll 1929-1932)

$\begin{array}{ll}\text { Infinitive } & \text { Imperative } \\ \text { anar 'to go' } & \text { bé/bés/vés } \\ \text { fer 'to do' } & \text { fés/fés/fé } \\ \text { veure 'to see' } & \text { bé/béw/bés/véw/váw } \\ \text { tenir/tindre 'to hold' } & \text { té/té/tén/tín } \\ \text { metre 'to put' } & \text { mét/mét/mát } \\ \text { tèmer 'to be afraid' } & \text { tém/tém/tám } \\ \text { fondre 'to melt' } & \text { fón } \\ \text { perdre 'to loose' } & \text { pért/péls } \\ \text { dur 'to carry' } & \text { dú/dúw/dús/dúf } \\ \text { dire 'to say' } & \text { dís/díw } \\ \text { venir 'to come' (boní, bindre) } & \text { bén/vén/bin/vine } \\ \text { viure 'to live' } & \text { bíw/víw }\end{array}$

Let us first point out that the verbs mentioned in (10) may have as well polysyllabic variants in some dialects. Second, if we take a closer look at the data from Catalan considering the historical source of the monosyllabic imperatives, we may ask ourselves whether their formation really obeys some Miminality Constraint. The verbs anar 'to go', fer 'to do', dir 'to say' and veure 'to see' have as second person singular imperative the forms vès, fès, dis, and vés. Is there, however, any phonological reason for having a CVC imperative in this case? The reason seems to be a morphological rather than a phonological one. Like many other Ibero-Romance varieties, the regularity concerning the formation of Catalan imperatives is that the second person singular imperative equals the third person singular present indicative: this is shown in Catalan, Aragonese, Asturian, Galician and Gascon among others. Thus the Catalan imperative of anar 'to go', fer 'to do', dir 'to say' and veure 'to see' should be va, fa, di and veu. If their second person singular imperative is vès, fès, dis, and vés, with a heavy syllable closed by [s], it is because the second person singular marker [s] has extended its scope from the $\mathrm{p} 2$ indicative to the imperative, as suggested by Moll (2006), Pérez Saldanya (1998) and others. In other words, given that the most frequent second person indicative forms 
are endowed with the person marker [s], this marker has been overgeneralized to imperatives where it is not etymologically justified. In a dialect like that of Algher ( ${ }^{\circ} 148$ in Moll's list), such an overgeneralization gives rise to the imperative pels 'loose!', where phonologically the syllable is super-heavy. This generalization does not apply to all verbs, however, given that we can find verb forms like te 'hold!', which lacks any person marker and appears to be subminimal. As pointed out by Fouché (1924: 125):

Dans le sens de 'voici' on emploie té ( $<$ tene). Mais si cet impératif conserve sa valeur verbale, il prend l'n devant une voyelle, tandis qu'il le prend ou non devant une consonne; cf. tén ú 'tiens-le'; tém bé ou té bé 'tiens bien' [In the sense of 'here it is', we use té ( $<$ tene). But if this imperative keeps its verbal value, $[\mathrm{n}]$ is preserved before a vowel, while it can be dropped or not before a consonant ; cf. tén ú 'hold it'; tém bé ou té bé 'hold good'].

It seems thus reasonable, following the observations of Fouché, to hypothesize that some kind of transcategorial shift is at least partly responsible for the particular phonological shape of this imperative form.

To sum up, the Catalan monosyllabic imperatives generally show up with a heavy syllable - CVC, CVG(lide) or CVCC - but one can find subminimal surface forms that seem to violate the bimoraic shape.

\subsubsection{Minimality in Italian}

The same kind of Minimality violation can be found in Italian. As was mentioned above, Minimality effects have been reported in Italian, and such Minimality effects have been argued to show up as well in Hypocoristic formations:

(11) The hypocoristics in Italian (Thornton 1996 and 2007)

$\begin{array}{lll}\text { (11a) Alessandro } & > & \text { Ale } \\ \text { (11b) Adriana/a } & > & \text { Adri } \\ \text { (11c) Antonella } & > & \text { Anto } \\ \text { (11d) Isabella } & > & \text { Isa } \\ \text { (11e) Edoardo } & > & \text { Edo ['Edo] } \\ \text { (11f) Patrizia } & > & \text { Patri } \\ \text { (11g) Fabrizio } & > & \text { Fabri } \\ \text { (11h) Teodoro } & > & \text { Teo } \\ \text { (11i) Federica } & > & \text { Fede }\end{array}$

The data in (11), which are drawn from Thornton (2007), consistently show that the hypocoristic derived from the full proper name is a left-headed bisyllabic word: We thus have Ale from Alessandro; Adri from Adriana; Anto from Antonella; Isa from Isabella, etc. 
When claiming that the minimal prosodic word in Italian is a Trochee, Thornton thus constrains herself to nominal expressions, leaving aside many strata of the Italian lexicon. Needless to say, there is no reason to limit the Minimality requirement to, say, the nominal, adjectival or adverbial classes. Incidentally, we should note with Bafile (1997: 450) that

(...) in Italiano non vige un requisito assoluto di minimalità del piede e quindi (...) della parola, e che le parole monosillabiche non debbano essere considerate marginali rispetto al fondo lessicale [Italian does not show any absolute requirement on foot and Word Minimality, and monosyllabic words should not be considered as marginal with respect to the lexical stock (...)].

In any case, the data in (12a) show that Italian does have monosyllabic imperatives whose syllable can be either light or heavy.

(12a) Italian monosyllabic imperatives (Huber-Sauter 1951: 65ff.; Floricic \& Molinu 2003, Mańczak 2004, Maiden 2007, etc.)

$\begin{array}{ll}\text { tenere 'to hold' /'keep' } & \text { te', tie' (< tieni) } \\ \text { togliere 'to take away, } & \text { to' (< togli) } \\ \text { guardare 'to look at' } & \text { gua' (< guarda) } \\ \text { vedere 'to see' } & v e \text { ' (< vedi) } \\ \text { aspettare 'to wait' } & \text { spe' (< aspetta) } \\ \text { dare 'to give' } & d a \text { ', dai } \\ \text { fare 'to do' } & f a \text { ', fai } \\ \text { stare 'to stay' } & \text { sta', stai } \\ \text { andare 'to go' } & v a \text { ', vai } \\ \text { trarre 'to pull' } & \text { trai } \\ \text { dire 'to say' } & d i \text { ' }\end{array}$

Indicative present tieni $(2 \mathrm{SG})$, tiene (3SG) togli $(2 \mathrm{SG})$, toglie (3SG) guardi $(2 \mathrm{SG})$, guarda $(3 \mathrm{SG})$ vedi $(2 \mathrm{SG})$, vede $(3 \mathrm{SG})$ aspetti (2SG), aspetta (3SG) dai $(2 \mathrm{SG}), d \grave{a}(3 \mathrm{SG})$ fai (2SG), fà (3SG) stai $(2 \mathrm{SG})$, stà (3SG) vai (2SG), va (3SG) trai $(2 \mathrm{SG})$, trae $(3 \mathrm{SG})$ $\operatorname{dici}(2 \mathrm{SG})$, dice (3SG)

From the data in (12a), it appears that the Italian monosyllabic imperatives are generally the truncated variant of the second person singular indicative (cf. te' / tie' from tieni, to' from togli, ve' from vedi, etc.). In the case of gua' (< guarda), and spe' (<aspetta), of course, the full imperative form is syncretic with third person present indicative. When two allomorphs are available, enclitics can attach to the monosyllabic root, while such an option is not available for the imperatives derived from polysyllabic roots. The enclitic forms in (12b) dammi 'give me!', fammi 'make me!', vammi 'go for me!', stammi 'stay me!', dimmi 'tell me!' are all grammatical, while forms like *tiello, *tollo, *vello, or guallo in (12c) are excluded:

(12b) Clitic attachment to monosyllabic roots:
i. $d a i \quad>$
dammi 'give me!'
ii. $f a i \quad>$
fammi 'make me!'
iii. vai >
vammi 'go for me!' 

iv. stai >
stammi 'stay for me!'
v. $\quad d i$ ' $>\quad$ dimmi 'tell me!'

(12c) Clitic attachment to polysyllabic roots
vi. te'tie' >
??tello/tiello (cf. tienilo 'keep it')
vii. to' $>$
??tollo (cf. toglilo 'take it off')
viii. ve' $>$
??vello (cf. vedilo 'see it / him')
xix. spe' >
??spello (cf. aspettalo 'wait for him/it')
xx. gua $^{\prime}>$
??guallo (cf. guardalo 'look at him/it')

The reason why clitic attachment is not possible with the monosyllabic imperatives derived from polysyllabic roots is that they have lost any valency property along with their phonetic reduction. The crucial question is then: how can we explain such a drastic reduction of the phonetic substance of the word? And how can we explain the subsequent subminimality observed in languages like Sardinian? Are we dealing with some kind of frequency-induced reduction, or is there any other parameter to call into question?

From a formal point of view, one may want to account for the phonological shape of imperatives in (12a) holding that at least some of them involve some Catalectic constituent (cf. Kiparsky 1991, Jacobs 1994, Kager 1995, etc.). In that case their apparent subminimality would just be a surface phenomenon and imperatives like ve' $(<$ vedi 'see!') and $f a$ ( $<f a i$ 'do!') should be given the representations in (12d):

(12d) i.

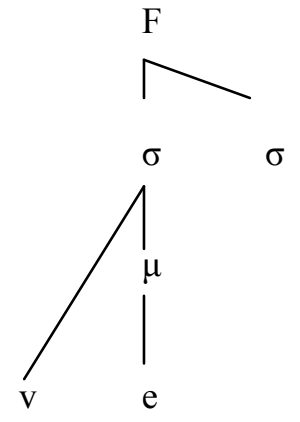

ii.

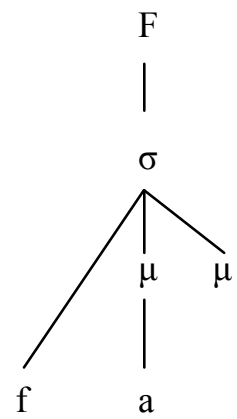

In the case of $v e^{\prime}$ in (12d-i), the catalectic element would be a syllable, while it would be a mora in the case of (12d-ii). The relevance of the catalectic mora in (12d-ii) would also be strengthened by the variation found in imperatives like failfa' ('do!'), vai/va' ('go!'), etc ${ }^{3}$. From our point of view, however, truncation must be accounted for at the

3 It could be claimed, with Nannucci (1843: 529ff., 552), that the Imperative of dare, stare, fare, andare, etc. regularly equals the present Indicative 3rd (SG) (cf. ama $[<$ amare]), and that da, sta, $f a, v a$ thus are 'primitive' Imperative forms which surface as a bare stem. This also is the view hold by D'Ovidio (1880: 220-221), who points out that they are the regular outcome of the corresponding Latin Imperatives, while dai, stai, fai, vai are borrowed from the (2nd SG) present Indicative. It must be recalled, first, that various verb forms entered the monosyllabic verb class 
phonological level, and there is no reason to hold that imperatives in (12) are phonologically wellformed. As mentioned above when discussing Catalan imperatives, we shall argue that these truncated imperatives are of course very frequent forms, but in addition they have shifted towards the category of Interjections: this shift is at least partly responsible for their phonetic reduction. It must be recalled that the frequency argument has already been put forth by Mańczak (2004), who states that

Si les changements phonétiques irréguliers dus à la fréquence se produisent à l'intérieur d'un paradigme flexionnel ou d'une famille de mots, les réductions ont lieu plus souvent dans les formes les plus fréquentes que dans les formes plus rares. [If phonetically irregular changes due to frequency occur inside a flexional paradigm or in a words family, these reductions more often affect the most frequent forms than the rarer ones.] (See as well Mańczak 1982)

And Mańczak (1980: 68) precisely takes our monosyllabic imperatives to be an example of this frequency-induced phonetic reduction: "In the same vein, the (Latin) imperative ending -e disappeared in the forms $f a c, d \bar{\imath} c, d \bar{u} c$, which are very often used".

Needless to say, it is the great merit of Witold Mańczak to have repeatedly argued, since the fifties, that frequency is a fundamental force in historical phonetics and morphological change. It is now recognized not as an epiphenomenon, but as a deep constraint on linguistic change: frequent forms are more easily stored in memory and their cognitive salience makes them more resistant to analogical levelling. Rather, frequent forms may form the starting point of paradigmatic restructuring. From this point of view, the works of Witold Mańczak deserve a special mention for their systematicity and their typological relevance. As regards truncated imperatives, it can be recalled that he importance of Überhäufigkeit had already been put forth by Schuchardt (1889) ${ }^{4}$ and Curtius (1886) as an explicandum of their reduction.

and levelled according to its general pattern. This is the case of $v a$ ( $<$ vade), which probably underwent the attraction of the above mentioned imperatives. Second, assuming that $d a, s t a, f a$, etc. are 'primitive' and dai, stai, fai, etc. somewhat 'secondary' (cf. D'Ovidio 1872: 67 and 1886: 86; Schuchardt 1874: 18; Huber-Sauter 1951: 19 fn.16) leads to the conclusion that Imperatives [da], [sta], [fa], [va] are the phonetic merger of different evolutionary pathways.

4 "Wir haben hier quantitative Veränderungen welche ausserhalb der 'Lautgesetze' liegen, und ihre Ursache ist in der Überhäufigkeit des gebrauches zu suchen; wie ich schon anderswo gesagt habe, kann man sich in solchen Fällen nicht auf Tonlosigkeit der Wörter beziehen, da diese selbst erst eine Folge der Überhäufigkeit ist, da ferner die sonst in unbetonten Silben herrschenden 'Lautgesetze' nicht beobachtet erscheinen und da endlich auch betonte Wörter bei Überhäufigkeit verkürzt werden (vgl. Imperative wie tosk. gua > guarda, span. to > toma)" (Schuchardt 1889: 529, footnote 1) [We have here quantitative changes which are beyond 'phonetic laws', and their cause can be found in high frequency of use; as I have already said elsewhere, one cannot refer in such cases to the stresslessness of the words, because this itself is only a consequence of high frequency, and because the 'phonetic laws' are not obeyed either in unstressed syllables, and finally because stressed words are also shortened due to high frequency (cf. imperatives like tosc. gua $>$ guarda, span. to $>$ toma]. 
The point to be stressed, however, is that following Mańczak, third person singular should count among the shortest verb forms. Instead, what the Italian and Sardinian evidence indicate is that our truncated imperatives are shorter than the corresponding third person singular verb forms. It thus follows that the shortness of our truncated imperatives cannot be said to be due to frequency. At most, frequency can be said to be a general property of some of the verbs referred to earlier. But the reason why our monosyllabic imperatives may be subminimal is that put forth by the great French dialectologist Georges Millardet, who observes that:

Historiquement l'impératif est, dans la conjugaison, une interjection verbale aussi brève que possible, réduite le plus souvent au radical inaltéré, avec ou sans

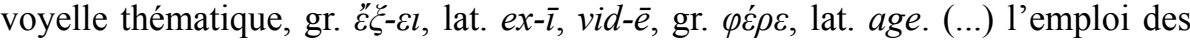
impératifs en qualité d'interjections entraîne pour ces formes verbales une certaine usure phonétique. Le même fait peut être constaté dans d'autres langues : ital. tę, vie, guar'; port. chete (Mistero, 113) = chegate, guarte, calte, tirte, porte (Millardet 1923: 441, 449). [Historically, the Imperative is, in conjugation, a verbal interjection as short as possible, most often reduced to the

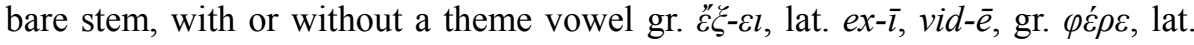
age. (...) The use of Imperatives as interjections leads them to some phonetic decay. The same fact can be observed in other languages: ital. te , vie, guar'; port. chete (Mistero, 113) = chegate, guarte, calte, tirte, porte $]$.

And the same observation can be found in the works of Meillet (1922) and Hofmann (1926). Of course, as pointed out by Meillet and Curtius, it cannot be excluded that the theme vowel is missing in those monosyllabic imperatives whose frequency rate is very high. However, given the general Ibero-Romance correlation between 3SG of the present indicative and 2SG of the imperative, and given the frequency of third persons, we should expect that the third person forms show up with a phonetic shape which is at least as reduced as that of the imperative. If reduced imperatives violate the phonological restrictions on Minimality, it is because they shifted towards the periphery of the language system, where the restrictions of the phonological system are less active. It is a crucial aspect of the analysis to recognize that lexicon and grammar are not a uniform and iso-functional system where the elements all have the same value, the same place and the same weight. Cumulative centers may be found, as well as 'free electrons' that escape the gravitational force of the system. Imperatives and Vocatives may have this status of 'free electrons' immune to the attraction of the center, hence a growing amount of phonological and morphological 'irregularities'. As was pointed out by Uspensky \& Zhivov (1977: 9) in their seminal work on Center and Periphery,

If we consider the periphery of langue (not parole) we can establish a general tendency expressed in the existence of anomalous structures in classes of peripheral elements, i.e., here the regularities inherent to the center of language do not hold." 
But of course, peripherality is not a matter of binarism and we should not expect a given pattern to be this or that: we are of course dealing with a continuum, and a given element or a given pattern may occupy different zones in such a continuum ${ }^{5}$. This is the case of our imperatives: at the same time inside and outside the core of the verb system.

\subsubsection{The case of Aragonese and Asturian}

Aragonese and Asturian imperatives will not be discussed at length because they show on the whole the same correlation between P3 of the present indicative and P2 of the imperative. This correlation is not so absolute, however, given that some imperative forms are shorter than the corresponding third person (SG) present indicative:

(13) Aragonese imperatives (Habla del Valle de Ansó)

\begin{tabular}{|c|c|c|}
\hline dá 'to give' (p.181) & $\begin{array}{l}\text { Imperative } \\
d a\end{array}$ & $\begin{array}{l}\text { Indicative present } \\
d a s(2 \mathrm{SG}), d a(3 \mathrm{SG})\end{array}$ \\
\hline 84) & tien & tienes $(2 \mathrm{SG})$, tiene $(3 \mathrm{SG})$ \\
\hline deci 'to say' (p.186) & $d i$ & dices $(2 \mathrm{SG})$, dice $(3 \mathrm{SG})$ \\
\hline$f e ́$ 'to do' (p.187) & fes & fas $(2 \mathrm{SG}), f a(3 \mathrm{SG})$ \\
\hline$i$ 'to go' (p.188) & ves & vas (2SG.), va (3SG) \\
\hline
\end{tabular}

As pointed out by Benítez Marco (2001: 170),

De hecho, el fenómeno [i.e. deletion of the theme vowel] sólo se atestigua en el verbo tené (tien), mientras que son regulares sale y viene, que presentan en castellano formas apocopadas. [In fact, this phenomenon (i.e. deletion of the theme vowel) only occurs with the verb tené (tien), while sale y viene are regular, which appear as apocopated in Castillan].

The imperative of the verb deci 'to say' however shows that the abbreviation process can lead to further reduction; as a matter of fact, the imperative $d i$ 'say' violates the integrity of the verb root, thus showing an irregular morphological pattern reminiscent of that found in other Romance languages. As for the verbs fé 'to do' and $i$ 'to go', they illustrate the same hypercharacterization as that mentioned in Catalan: the final consonant of imperatives fes and ves is not etymological, nor does require any phonologically-grounded explanation ${ }^{6}$. In the Asturian dialect spoken in Parres, it can

5 Cf. Daneš (1966: 14): "[...] there does not exist any clear line separating $C$ and $P$, but a continuous transitional zone. While there certainly exist phenomena situated "in the very centre" or "in the obvious periphery", one cannot overlook the existence of items which can only be denoted as "more central" (or, respectively, "more peripheral") than others. In short, the central and the peripheral character are qualities revealed by different items of the language system in different degrees (and in view of the fact that the transitions appear to be continuous it would hardly make sense to establish any exactly defined degrees of peripheral character)".

6 If the adjunction of final $-s$ does not rely on any phonological restriction, on the other hand its deletion with enclitics obeys such restrictions (cf. Benítez Marco 2001: 168). In other words the 
be pointed out that the imperative ve 'go!' of the verb dir does not surface with any morphological exponent, nor does the imperative fay 'do!' of the verb facer:

(14) Asturian (Vallina Alonso 1985: 172-173)

\begin{tabular}{|c|c|c|}
\hline & Imperative & Indicative present \\
\hline tener 'to have' & ten & tienes/ties (2SG), tien (3SG) \\
\hline facer 'to do' & $f a y, f a$ & faces, faes (2SG), fay, fa (3SG) \\
\hline dicer, dicir 'to say' & $d i$ & $\operatorname{dices}(2 \mathrm{SG}), \operatorname{diz}(3 \mathrm{SG})$ \\
\hline poner 'to put' & pon & pones $(2 \mathrm{SG})$, pon $(3 \mathrm{SG})$ \\
\hline \multirow[t]{3}{*}{ trayer/trer 'to bring } & tray & trayes $(2 \mathrm{SG})$, tray $(3 \mathrm{SG})$ \\
\hline & tre & $\operatorname{tres}(2 \mathrm{SG}), \operatorname{tra}(3 \mathrm{SG})$ \\
\hline & trai & $\operatorname{traes}(2 \mathrm{SG})$, trae $(3 \mathrm{SG})$ \\
\hline ver 'to see' & ve & ves $(2 \mathrm{SG})$, ve $(3 \mathrm{SG})$ \\
\hline dir 'to go' & ve & vas $(2 \mathrm{SG}), v a(3 \mathrm{SG})$ \\
\hline venir 'to come' & ven & vienes $(2 \mathrm{SG})$, vien $(3 \mathrm{SG})$ \\
\hline dar 'to give' & $d a$ & $\operatorname{das}(2 \mathrm{SG}), d a(3 \mathrm{SG})$ \\
\hline ller 'to read' & lle & lles $(2 \mathrm{SG})$, lle $(3 \mathrm{SG})$ \\
\hline
\end{tabular}

While most of the imperatives mentioned above seem to be syncretic with third person singular indicative forms, such a correlation is less general in Asturian than in Aragonese or Catalan. Putting aside the case of verb forms like di 'say!' from dicer, dicir, whose phonetic reduction has already been discussed, and the case of monophtongized imperatives ten! 'hold' and ven! 'come', imperatives of the -er class surface with final $-i$ in the imperative, while the third person singular (present indicative) shows up with final -e in Parres (cf. imp. corri 'run!' ( cuerre (3SG)); cueyi 'catch!' ( cueye (3SG)); viendi 'sell!' ( viende (3SG)), etc. (Vallina Alonso 1985: 146, $171,174)$. In the dialect of Lena, the contrast between the imperative $(2 \mathrm{SG})$ and the indicative has as exponent the metaphony of the stressed vowel, hence the pairs bibe 'drink!' (2SG) bebe (3SG); prinde 'take!' (2SG) prende (3SG); vinde 'sell!' (2SG) vende (3SG), etc. (cf. Neira 1962: 387) ${ }^{7}$.

\subsubsection{Imperatives and Minimality in Portuguese}

For lack of space, the question of Portuguese imperatives will be adressed only briefly. The hypocoristics in (15) indicate that Brazilian Portuguese phonology is not governed

enclisis of pronominal markers implies the selection of the bare allomorph. The same pattern can be observed in Alguerese, where Bosch i Rodoreda (2002: 172) mentions verbal forms like fes-la [fela], fes-me [feme], etc.

7 The question of the nature and origin of metaphony in this verb class still is object of debate. It has been argued that final $-i$ of imperatives in -ire verb class has been extended to the verb class in -er, where we should not expect metaphony. Needless to say, this question would require an indepth discussion which cannot be addressed in this paper. 
by a minimal size restriction. As a matter of fact, these data drawn from Grau Sempere (2006) show that in Brazilian Portuguese, hypocoristics may have the shape of a trochee, be it syllabic or moraic. With paroxitone bases, we thus have nouns like vál.du $(<$ os.vál.du), lí.pe $(<$ fe.lí.pe), náa.du $(<$ fer.ná.du) and pów.du $(<$ le.o.pów.du); with oxitone bases, we can register nouns like kéw (< ra.kéw); néw $(<$ i.ri.néw); géw $(<$ mi.géw) and már (ma.ri.már):

(15) Portuguese hypocoristics I (Grau Sempere 2006: 123): Portuguese Paroxitone base Base Trunc.

Oxitone base os.vál.du vál.du

$(15 \mathrm{c})$ ferina du

(15d) le.o.pów.du pów.du

Base Trunc.

This is not the only option, however, and the data in (16) show that Brazilian Portuguese may well form monosyllabic and monomoraic hypocoristics:

(16) Portuguese hypocoristics II (Grau Sempere 2006: 125): Portuguese Paroxitone base Oxitone base Base

Trunc.

(16a) aj.váw.ni

(16b) áw.ba

(16c) á.na

(16d) a.ná.dzi

(16e) ar.náw.du

(16f) aw.dér.li ni

$b a ́$

ná

dsi

$d u ́$

lí (15e) ra.kéw

(15f) i.ri.néw

(15g) mi.géw

(15h) ma.ri.már kéw

néw

géw

már

In examples $(16 \mathrm{a}-\mathrm{f})$, the hypocoristic selects the final syllable of a paroxytone base, regardless of its syllable weight. In examples $(16 \mathrm{~g}-1)$, on the other hand, it is the stressed syllable of the oxytone base which is selected as hypocoristic, but forms like "a" $(<$ Aleksandre), "e" $(<$ Eduardu) or "i" $(<$ Inasio $)$ reported by Grau Sempere seem to show that the Portuguese hypocoristics can select as well the initial vowel of the noun, albeit unstressed ${ }^{8}$. Grau Sempere (2006: 133) thus concludes that "Brazilian

8 It is not sure whether all the monosyllabic forms reported by Grau Sempere are equally acceptable. Some Brazilian Portuguese speakers seem to reject such hypocoristics as ['a] for Aleksandre, thus raising the question of the real status of these forms. Gonçalves (2005) rejects such monosyllabic hypocoristics as Bé (< Barnabé), Mé (< Salomé), or Dé (<André), as well as trisyllabic forms like Nélope (< Penélope), Mérico (< Américo) or Ripedes (< Eurípedes), but Thami da Silva (2008) mentions such truncated nouns as Mé (< Américo), Tá (< Itamar) $S i ́$ (< Simone) Fê $(<$ Fernanda) or Sú (< Sueli) that seem to contradict Gonçalves' assumption. Interestingly, Thami da Silva (2008: 88 fnt. 16 and 108) points out that the final vowel of such forms can be lengthened, and that such lengthening should be viewed as an effect of their Vocatival use (cf. on this point Floricic 2010a). 
Portuguese is the only Ibero-Romance dialect that accepts monomoraic monosyllabic Type R truncated words".

Turning now to imperatives, the examples in (17) show that the correlation P3 of the present indicative and P2 of the imperative holds as well for Portuguese. Furthermore, the monosyllabic imperatives in (17) show that CVC and CV imperatives are both attested, thus arguing for the absence of a minimal size restriction in Portuguese.

(17) Portuguese imperatives

\begin{tabular}{|c|c|c|}
\hline & Imperative & Indicative present \\
\hline fazer 'to do' & $f a z$ & fázes (2SG), faz (3SG) \\
\hline trazer 'to carry' & traz, traze & trazes $(2 \mathrm{SG})$, traz $(3 \mathrm{SG})$ \\
\hline dizer 'to say' & $d i z$ & $\operatorname{dizes}(2 \mathrm{SG}), \operatorname{diz}(3 \mathrm{SG})$ \\
\hline dar 'to give' & $d a ́$ & dás (2SG), dá (3SG) \\
\hline \multirow[t]{3}{*}{ olhar 'to look' } & olha/olh/o & \\
\hline & (cf. French $\operatorname{ard!}$ [ard] & \\
\hline & < regarde! [RəgaRd]) & olhas $(2 \mathrm{SG})$, olha $(3 \mathrm{SG})$ \\
\hline deixar 'to let' & deixa/xá & deixas $(2 \mathrm{SG})$, deixa $(3 \mathrm{SG})$ \\
\hline ir 'to go' & $v a i / v a$ & vais (2SG), vai (3SG) \\
\hline vir 'to come' & vem & vens $(2 \mathrm{SG})$, vem $(3 \mathrm{SG})$ \\
\hline rir 'to laugh' & $r i$ & $r i s(2 \mathrm{SG}), r i(3 \mathrm{SG})$ \\
\hline ler 'to read' & $l \hat{e}$ & lês $(2 \mathrm{SG}), l \hat{e}(3 \mathrm{SG})$ \\
\hline ver 'to see' & $v \hat{e}$ & vês $(2 \mathrm{SG}), v e \hat{e}(3 \mathrm{SG})$ \\
\hline
\end{tabular}

Some of the imperatives in (17) - that is, faz, diz, traz, vai, tem and vem could of course be said to match the minimal moraic trochee requirement of Brazilian Portuguese argued for by Carlos Alexandre Gonçalves (2005). It is clear, however, that not all the monosyllabic imperatives obey this requirement. For example dá, va, lê, vê, crê, etc. all are monosyllabic and monomoraic. We can even find imperatives like olh 'look!' alongside with olha. In this case, it will be noted that the imperative can lose the thematic vowel, and the amputation of the verb form can even lead to the variant [0], which really is what Gilliéron (1915), Millardet (1923) and others called "un mutilé phonétique": not only does it show a drastic reduction of the verb root, but it also illustrates the semantic shift referred to earlier: in other words, the reduced forms olh/o have shifted towards the status of discourse marker and they lost any verbhood ${ }^{9}$. The

\footnotetext{
9 “Como foi dito no 8.8, há verbos que costumam ser utilizados pelo falante para marcar troca de turnos numa conversação ou para introduzir um novo assunto. Partimos da hipótese de que verbos como olhar, deixar e esperar, em princípio usados como marcadores do discurso, estariam adquirindo status de forma cristalizada e, portanto, favorecendo mais o imperativo associado ao indicativo. O que motivou o controle desta variável foi o fato de observarmos que as formas gramaticalizadas de esperar, deixar e olhar já se apresentarem gramaticalizadas em formas diretamente associadas ao imperativo no indicativo: peraí, xá (xá comigo), óia" (Teixeira de Jesus 2006: 114) [As mentioned in 8.8, there are verbs that are often used by the speaker to mark turn
} 
same observation holds for the imperative form $x a$ a $(<$ deixa), which is obtained by aphaeresis, a deletion process which applies on the symetrical side of the word ${ }^{10}$. This form mainly appears in the expression xá comigo 'it's up to me', where it is somewhat petrified.

\subsubsection{Imperatives in Gascon}

We shall close this brief overview with a sketch of monosyllabic imperatives in an Occitan variety - Gascon - which is close enough to Catalan to exempt us from giving a detailed presentation of the data. We shall not say anything either on the syntax of this variety, though it should be pointed that Gascon normally uses preverbal particles (termed 'énonciatifs' in the linguistic literature on this topic) as predicative markers. These markers, however, do not surface with imperatives, nor do they generally surface with negation (for a discussion see Floricic 2009). The data in (18) interestingly show that Gascon patterns with Ibero-Romance as far as imperative morphology is concerned:

(18) Gascon (Massourre 2001: 150ff.)

\begin{tabular}{|c|c|c|}
\hline & Imperative & Indicative present \\
\hline$a^{\prime} n a$ 'to go' & $' b \varepsilon(\mathrm{n})$ & 'bas (2SG), 'ba (3SG) \\
\hline 'be 'to come' & 'be, 'ben, 'bene & 'bes (2SG), 'be (3SG) \\
\hline 'da 'to give' & 'da & 'das (2SG), 'da (3SG) \\
\hline 'prene 'to take' & 'pren & 'prenes (2SG), 'pren (3SG) \\
\hline 'he 'to do' & 'he & 'hes (2SG), 'he (3SG) \\
\hline sen'ti 'to feel' & sen'tef/'sen & $\begin{array}{l}\text { sen'tefes/'sentes }(2 \mathrm{SG}) \text {, } \\
\text { sen'tef/'sen }(3 \mathrm{SG})\end{array}$ \\
\hline 'te 'to hold' & 'te & 'tes (2SG), 'te (3SG) \\
\hline 'beße 'to drink' & 'bew & 'beßes (2SG), 'bew (3SG) \\
\hline sa'ße 'to know' & 'sap & 'saßes (2SG), 'sap (3SG) \\
\hline dru'mi 'to sleep' & 'drum & 'drumes (2SG), 'drum (3S \\
\hline
\end{tabular}

Not only does Gascon imperative morphology pattern with that of Ibero-Romance; it shows as well the same syncretisms and the same idiosyncrasies as that mentioned in Aragonese and Catalan. The verb 'be 'come!' ( $<$ 'be 'to come') has at least three

changes in conversation or to introduce a new topic. Our hypothesis is that verbs like olhar, deixar and esperar, normally used as discourse markers, would be acquiring the status of crystallized forms, and thus, would be favouring the imperative associated with the indicative. What motivated the verification of this variable is the observation that the grammaticalized forms of esperar, deixar and olhar already present themselves as grammaticalized in forms directly linked to the imperative in the indicative: perai, xá (xá comigo), óia].

10 The exceptional reduction of this form is not more surprising than that found in Lombard or Molisan, where the same kind of amputation leads to ssa/sa (< ássa < lássa [cf. D'Ovidio 1878: 168; Salvioni 1895: 127-128; Bovet 1901: 253]). 
allomorphs - 'be, 'ben, 'bene (Massourre 2005: 262) - whose shape has long been discussed. Most view in the final consonant $-n /-n e$ the outcome of the partitive/locative marker -ne $(<$ inde). The same observation holds for the form 'be(n)! 'go!' $(<a$ 'na 'to go'), whose final'- $n$ has been deemed to have the same origin (for a discussion see Floricic 2010b). In this case it will be observed that the imperative verb form does not surface with any person marker, as seen with Catalan vés/bés. No hypercharacterization shows up here, nor does it show up with the verb ' $h \varepsilon$ 'to do' ( $<$ facere), whose imperative is syncretic with the present indicative third person singular. To conclude, it is worth pointing out that in Gascon this syncretism ( 2 p. imp. $=3 p$. pres. ind.) even holds in cases where Catalan would resort to subjunctive forms. For instance, the verb $s a$ 'ße 'to know' has as imperative the form 'sap, while Catalan generally has sapigues / sapiguis/sabis. Another correlation with Catalan, however, can be seen in the imperatives sen'tefl'sen 'feel!' ( $<$ sen'ti (sentīre)): the allomorph sen'tef has the same extension as that found in verbs like menteix [man't $\varepsilon](<$ man'ti (mentīiri)), parteix $\left[p \partial r^{\prime} t \varepsilon\right]$ (< par'ti (partìre)), etc. Needless to say, the interdialectal and intradialectal variation found in Catalan and Occitan imperatives should deserve a much more detailed analysis (see Floricic 2010b). We hope at least to have shown that morphology and phonology interact in such way as to question the relevance of purely phonological constraints in their make-up.

\section{Conclusion}

Minimality restrictions have been argued to be at work in many languages over the world. However, the violations of such restrictions have not yet received the attention that they deserve. Romance monosyllabic imperatives show that imperatives may violate phonological constraints when they lose their verb-hood and shift towards interjections or discourse markers; in addition, it is questionable whether Minimality restrictions should be viewed as heavy constraints applying to the lexicon as a whole. Imperatives, vocatives, and loans are a privileged field where anomalous patterns may be found (cf. Isačenko 1964, Floricic 2002, Floricic \& Molinu 2003, etc.), and we have taken minimal size violations in imperatives to be due to their appeal value. Crucially, imperatives like vocatives appear to be the mirror image of hypocoristics concerning phonological markedness. In this case, we should talk about the "emergence of the marked" instead of the "emergence of the unmarked". This concept of "markedness', it must be pointed out, does not dissolve in 'frequency of use' or in high articulatory cost: in an imperative form like Sardinian mi' ['mi] 'look!' there is nothing a priori that would make it 'marked' from the point of view of 'production'/"perception', or from the point of view of frequency; on the contrary: it is an optimal CV syllable provided with an onset and a rime, and it is rather a frequent form. All the properties of this imperative should thus assign it an 'unmarked' status. But the markedness of this imperative only 
stems from its structural position within the Sardinian phonological system: Sardinian phonology only allows bisyllabic trochees as minimal words, a constraint which is violated by some imperatives, by vocatives and by interjections. What these categories have in common is a) their speech-rooted character; b) their peripherality with respect to the structural make-up of the language: they tend to escape the network of syntagmatic and paradigmatic relations in which any given element of the language is inserted. They are the 'free electrons' of the language and this is the main reason for their structural deviance.

\section{References}

Bafile, Laura (1997): Parole grammaticali e struttura prosodica: dati dell'italiano e del napoletano, in: Lingua e Stile 32(3), 433-469.

Benítez Marco, Maria Pilar (2001): L'ansotano. Estudio del habla del Valle de Ansó. Zaragoza: Gobierno de Aragón.

Bosch i Rodoreda, Andreu (2002): El català de l'Alguer. Barcelona: Publicacions de l'Abadia de Montserrat.

Bovet, Ernesto (1901): Ancora il problema di andare, in: Scritti vari di filologia. A Ernesto Monaci per l'anno XXV del suo insegnamento - gli scolari. Roma: Forzani \& C., 243-262.

Cabré i Monet, Teresa (1993): Estructura gramatical i lexicó: el mot mínim en Català. Barcelona: Departament de Filologia Catalana (Tesi Doctoral).

Cabré i Monet, Teresa (1994): Minimality in the Catalan truncation process, in: Catalan Working Papers in Linguistics 4(1),1-21.

Curtius, Georg (1886): Principles of Greek etymology. London: John Murray (translated by A. S. Wilkins \& E. B. England).

Daneš, František (1966): The relation of centre and periphery as a language universal, in: Vachek, J. (ed.), Travaux linguistiques de Prague 2. Les problèmes du centre et de la périphérie du système de la langue. Prague: Academia/Paris: Klincksieck, 9-21.

D’Ovidio, Francesco (1872): Di alcune parole che nella pronunzia producono il raddoppiamento nella consonante iniziale della parola seguente, in: Il Propugnatore 5(1), 64-76.

D’Ovidio, Francesco (1878): Saggi critici. Napoli: Domenico Morano.

D’Ovidio, Francesco (1880): La lingua dei Promessi Sposi: nella prima e nella seconda edizione. Napoli: Domenico Morano.

D’Ovidio, Francesco (1886): Ricerche sui pronomi personali e possessivi neolatini, in: Archivio Glottologico Italiano 9, 25-101.

Downing, Laura J. (2000): Satisfying minimality in Ndebele, in: ZAS Papers in Linguistics 19, 23-39.

Floricic, Franck (2002): La morphologie du Vocatif: l'exemple du sarde, in: Vox Romanica 61, 151-177.

Floricic, Franck (2009): Negation and 'focus clash' in Sardinian, in: Mereu, Lunella (ed.), Information structure and its interfaces. Berlin/New York: Mouton de Gruyter, 129-152.

Floricic, Franck (2010a): Le vocatif et la périphérie du système des cas: exemples italo-romans et slaves (ms).

Floricic, Franck (2010b): Notule sur l'impératif catalan vine 'viens !' (ms) 
Floricic, Franck \& Molinu, Lucia (2003): Imperativi 'monosillabici' e 'Minimal Word' in italiano 'standard' e in sardo, in: Actes du XXXV Congresso internazionale di Studi della SLI. "Il verbo italiano - Approcci diacronici, sincronici, contrastivi e didattici” (Paris, 20-22 septembre 2001). Roma: Bulzoni, 343-357.

Fouché, Pierre (1924): Phonétique historique du Roussillonnais. Toulouse: Edouard Privat.

Gauthiot, Robert (1913): La fin de mot en Indo-Européen. Paris: Paul Geuthner.

Gilliéron, Jules (1915): Pathologie et thérapeutique verbales. Canton de Berne (Suisse) : Beerstecher.

Gonçalves, Carlos A. (2005): Relações de identidade em modelos paralelistas: morfologia e fonologia, in: D.E.L.T.A. 21(1), 75-119.

Grau Sempere, Antonio (2006): Conflicting quantity patterns in Ibero-Romance prosody. Austin: The University of Texas at Austin (Doctoral Dissertation).

Herman, Rebecca (1996): Prosodic structure in SiSwati, in: Ohio State University Working Papers in Linguistics 48, 31-55.

Hofmann, Johann Baptist (1926): Lateinische Umgangsprache. Heidelberg: Winter (italian translation: La lingua d'uso latina. Introduzione, traduzione italiana e note a cura di Licinia Ricottilli)

Huber-Sauter, Margrit (1951): Zur Syntax des Imperativs im Italienischen. (Romanica Helvetica 36) Zürich: J. Weiß.

Hyman, Larry (2008): Directional asymmetries in the morphology and phonology of words, with special reference to Bantu, in: Linguistics 46(2), 309-350.

Hyman, Larry; Inkelas, Sharon \& Sibanda Galen (2008): Morphosyntactic correspondence in Bantu reduplication, in: Hanson, Kristine \& Inkelas, Sharon (eds.), The nature of the word: studies in honor of Paul Kiparsky. Cambridge: The MIT Press, 273-309.

Isačenko, Alexander V. (1964): On the conative function of language, in: Vachek, J. (ed.), A Prague School Reader in Linguistics. Bloomington: Indiana University Press, 88-97.

Jacobs, Haike (1994): Catalexis and stress in Romance, in: Mazzola Michael L. (ed.), Issues and theory in Romance linguistics. Selected papers from the linguistic symposium on Romance languages XXIII (April 1-4, 1993). Washington, DC: Georgetown University Press, 49-65.

Kager, René (1995): Consequences of catalexis, in: van der Hulst, Harry \& van de Weijer, Jeroen (eds.), Leiden in Last. HIL Phonology Papers I. The Hague: Holland Academic Graphics, 269-298.

Kiparsky, Paul (1991): Catalexis. Ms. Stanford University and Wissenschaftskolleg zu Berlin.

Kraska-Szlenk, Iwona (2009): Size vis-à-vis frequency: minimality and maximality constraints in Swahili, in: Language Sciences 31, 271-284.

Kruszewski, Mikołaj (1883/1995): Outline of linguistic science, in: Writings in general linguistics. Amsterdam/Philadelphia: John Benjamins, 34-178.

Lombard, Alf (1953): Un groupe d'impératifs abrégés en roumain, in: Studia Neophilologica 25, 21-39.

Maiden, Martin (2007): On the morphology of Italo-Romance imperatives, in: Bentley, Delia \& Ledgeway, Adam (eds.), Sui dialetti italoromanzi. Saggi in onore di Nigel B. Vincent. Cambridge: University of Cambridge, 148-164.

Mańczak, Witold (1980): Irregular sound change due to frequency in Latin, in: Language Sciences 2, $62-68$.

Mańczak, Witold (1982): Fonetica e morfologia storica dell'italiano. Kraków: Uniwersytet Jagiellonski.

Mańczak, Witold (2004): Certaines formes de l'impératif en italien et en sarde, in: Swiatkowska, Marcela; Sosnowski, Roman \& Piechnik, I. (eds.), Maestro e Amico. Miscellanea in onore di 
Stanisław Widłak. Mistrz i Przyjaciel. (Studia dedykowane Stanisławowi Widłakowi). Kraków: Wydawnictwo UJ, 231-234.

Massourre, Jean-Louis (2001): Le dialecte des vallées de Luz, de Barèges et de Gavarnie. Aperçus géographiques et historiques, phonétique, morphologie nominale et pronominale, mots invariables, morphologie verbale, tiroirs verbaux, dérivation et préfixation, notes de syntaxe, glossaire thématique, glossaire général. Thèse de Doctorat (Université de Toulouse 2-Le Mirail).

Massourre, Jean-Louis (2005): Le Gascon. "Lengatge estranh ». Pech de Rayssac: Jean-Louis Massourre.

Meillet, Antoine (1900): Notes sur quelques faits de morphologie. VI. De quelques aoristes monosyllabiques en arménien, in: Mémoires de la Société de Linguistique de Paris 11, 16.

Meillet, Antoine (1905-1906): Observations sur le verbe latin, in: Mémoires de la Société de Linguistique de Paris 13, 350-375.

Meillet, Antoine (1922): Review of: Horn, Wilhelm (1921), Sprachkörper und Sprachfunktion. Mayer \& Muller, Berlin, in: Bulletin de la Société de Linguistique de Paris 23(2), 33-35.

Millardet, Georges (1923): Linguistique et dialectologie romanes. Problèmes et méthodes. Montpellier: Société des langues romanes/Paris: Champion.

Molinu, Lucia (1988-1989): Morfologia verbale del Buddusoino (varietà logudorese di Buddusò). Tesi di Laurea dell'Università di Pisa.

Molinu, Lucia (1999): Morfologia logudorese, in: Bolognesi, Roberto \& Helsloot, Kees (eds.), La lingua sarda. L'identità socioculturale della Sardegna nel prossimo millennio. Atti del Convegno di Quartu Sant'Elena, 9-10 maggio 1997. Cagliari: Condaghes, 127-136.

Moll, Francesc de B. (1929-1932): La flexió verbal en els dialectes catalans, in: Anuari de l'Oficina Romanica de Lingüistica i Literatura 2-5, 73-184, 73-168, 9-104, 9-72.

Moll, Francesc de B. (2006), Gramàtica històrica catalana. València: Universitat de València.

Nannucci, Vincenzo (1843): Analisi critica dei verbi italiani investigati nella loro primitiva origine. Firenze: Le Monnier.

Neira, Jesús (1962): La metafonía en las formas verbales del imperativo y del perfecto. (Adiciones al "Habla de Lena"), in: Archivum 12, 383-393.

Park, Jae-Ick (1998): Minimal word effects with special reference to Swahili. Indiana University (Doctoral Dissertation)

Pérez Saldanya, Manuel (1998): Del llati al català. Morfosintaxi verbal històrica. València: Universitat de València.

Salvioni, Carlo (1895): Dialetti dell'Alta Italia, in: Kritischer Jahresbericht über die Fortschritte der romanischen Philologie 1, 120-132.

Schuchardt, Hugo (1874): Phonétique comparée. Les modifications syntactiques de la consonne initiale dans les dialectes de la Sardaigne, du centre et du sud de l'Italie, in: Romania 3, 1-30.

Schuchardt, Hugo (1889): Romanische Etymologien, in: Zeitschrift für Romanische Philologie 13, 525-553.

Teixeira de Jesus, Etel (2006): O Nordeste na mídia e os estereótipos linguísticos: estudo do imperativo na novela Senhora do Destino. Dissertação (Mestrado em Letras). Brasília.

Thami da Silva, Hayla (2008): Uma abordagem otimalista da Hipocorização com padrão de cópia à esquerda. Dissertação (Mestrado em Letras). Universidade Federal do Rio de Janeiro

Thornton, Anna Maria (1996): On some phenomena of prosodic morphology in Italian: accorciamenti, hypocoristics and prosodic delimitation, in: Probus 8, 81-112. 
Thornton, Anna Maria (2007): Phénomènes de réduction en italien, in: Delais-Roussarie, Elisabeth \& Labrune, Laurence (eds.), Des sons et des sens. Données et modèles en phonologie et en morphologie. Paris: Lavoisier, 241-268.

Uspensky, Boris A. \& Zhivov, Viktor M. (1977): Center-periphery opposition and language universals, in: Linguistics 196, 5-24.

Vallina Alonso, Celestina (1985): El habla del Sudeste de Parres (Desde el Sella hasta El Mampodre). Oviedo: Instituto de Estudios Asturianos.

Viruete Erdozáin, Ricardo (2007-2008): Aproximació a la morfologia verbal del català de Benavarri (Osca), in: Archivo de Filología Aragonesa 63-64, 99-128.

Wackernagel, Jacob (1953): Wortumfang und Wortform, in: Wackernagel, Jacob (ed.), Kleine Schriften. 1. Göttingen: Vandenhoeck und Ruprecht, 148-185. 